\title{
IMPACT OF HUMAN ACTIVITIES AND INFRASTRUCTURE WORKS ON HYDRO MORPHOLOGICAL CHARACTERISTICS OF ALFEIOS RIVER, GREECE
}

\author{
MANARIOTIS I.D. \\ YANNOPOULOS P.C.*
}

\author{
Environmental Engineering Laboratory \\ Department of Civil Engineering \\ University of Patras, 26504 Greece
}

Received:19/10/2012

Accepted:07/10/2013 *to whom all correspondence should be addressed: e-mail: yannopp@upatras.gr

\section{ABSTRACT}

The Alfeios River is the greatest in length and flow-rate river in Peloponnisos and constitutes an important water resource and ecosystem of Western Greece. A number of infrastructure works and human activities have been constructed and are operating in Alfeios River Basin, while in the past extensive gravel extraction occurred. The impacts of infrastructure works and gravel extraction mainly in the Lower Alfeios Basin on the hydromorphological river characteristics are described and analyzed. Increased conductivity values were observed at the position close to the steam electric power plant due to the discharge of wastewater. The results show that gravel extraction and infrastructure works, in conjunction with the reduced sediment transport rates, cause long-term adverse effects on riverbed erosion as well as on the water level.

KEYWORDS: Water quality; riverbed changes; gravel extraction; river basin management.

\section{INTRODUCTION}

Many processes taking place in the river basin affect the quality of freshwater directly or indirectly. Anthropogenic activities in river basins include gravel extraction, coal mining, extensive urbanization, land and water uses, agro-industrial units, and wastewater disposal. Anthropogenic activities alter water quality not only by changing the hydrologic pathways, but also by the addition of pollutants via point and non-point sources to the river basin (Carpenter et al., 1998; Dassenakis et al., 1998; Peters and Meybeck, 2000; Simeonov et al., 2003; Kepner et al., 2004; Massoud et al., 2006; Absalon and Matysik, 2007). The deterioration of water quality limits water use for drinking, agricultural and recreational and other purposes.

Gravel extraction can have both immediate and long-term consequences for channel stability. Changes to channel morphology are initiated through the lowering of the riverbed during gravel extraction (Rinaldi et al., 2005). River gravels are a particularly attractive source of aggregate as they are relatively well sorted, easily accessible and relatively cheap to extract. During the decade 1990-2000, commercial gravel extraction has declined due to strict regulations (Manariotis and Yannopoulos, 2004; Wishart et al., 2008; Bekri and Yannopoulos, 2012). Instream gravel mining involves the mechanical removal of gravel and sand from the riverbed which directly affects channel geometry and bed level (Kondolf, 1994). Furthermore, instream gravel mining affects the stability and safety of infrastructure works (i.e. bridges, dams) causing scour and under excavation of their foundation, lowering the water table, and resulting in riparian habitat losses (Kondolf, 1994; Manariotis and Yannopoulos, 2001).

The construction and operation of infrastructure works, in conjunction with continued gravel extraction, are linked to geomorphologic alterations, which cause adverse environmental impacts and affect water resources, thereby causing ecosystem deterioration (Dafis et al., 1996; ETME, 1997). The geomorphological input to river management is potentially considerable, and contributes to prevailing arguments about habitat structure and dynamics in freshwater ecology (Newson and Newson, 2000). In recent years, intensive use of natural resources in Greek river basins has been 
observed. Anthropogenic pressures often exceed water regeneration rates. Furthermore, changes of the natural boundaries of the river beds often occur (Manariotis and Yannopoulos, 2004).

Significant impacts have been recorded on the geomorphologic characteristics, especially in the lower basin of Alfeios River. Nicholas et al., (1999) studied the impact of protection and irrigation works, the embankments and the dam on the river bed erosion in relation with the gravel extraction. According to their results, the total volume of the gravel extracted from 1967 to 1995 was estimated to be approximately $17,6 \times 10^{6} \mathrm{~m}^{3}$ and caused a cumulative retreat of river bed in the area of gravel extraction (8 $\mathrm{km}$ length and $250 \mathrm{~m}$ width) of about $9 \mathrm{~m}$.

The aim of this paper is to assess the effects of human activities on the water quality of the Alfeios River and to examine the spatial relationship between main anthropogenic activities and physicochemical water quality characteristics across the river. Furthermore, the impacts of gravel extraction in the Lower Alfeios Basin on the hydro-morphological river characteristics and infrastructure works were also assessed.

\section{DESCRIPTION OF THE AREA}

The Alfeios River is the longest $(112 \mathrm{~km})$ watercourse in the Peloponnisos region of Greece with an annual water yield $2100 \times 10^{6} \mathrm{~m}^{3}$ (Figure 1). Alfeios drainage area is extended to the central and western Peloponnisos and can be divided in three parts (sub basins), the upper $\left(250 \mathrm{~km}^{2}\right)$, the middle $\left(3048 \mathrm{~km}^{2}\right)$, and the lower sub basin $\left(362 \mathrm{~km}^{2}\right.$ ) (Manariotis and Yannopoulos, 2004). The Alfeios River basin including the River Delta constitutes a significant ecosystem and natural resource (water, alluvial gravel, lignite, fauna and flora) for three prefectures, Ileia, Arkadhia and Achaia.

Table 1. Infrastructure projects and gravel extraction activities in the Alfeios River Basin

\begin{tabular}{|c|c|}
\hline Year & Project/Activity \\
\hline 1951 & $\begin{array}{l}\text { Gravity dam at Tropaia (artificial reservoir: surface } 4 \mathrm{~km}^{2} \text {, storage volume } 46.2 \mathrm{x} \\
10^{6} \mathrm{~m}^{3} \text {, basin } 749 \mathrm{~km}^{2} \text { ) }\end{array}$ \\
\hline 1955 & Ladhon hydroelectric station, $8620 \mathrm{~m}$ downstream of dam (operated after 2 years) \\
\hline 1965 & Construction of embankments in Lower Alfeios Basin (8.6 km length, $250 \mathrm{~m}$ width) \\
\hline 1967 & $\begin{array}{l}\text { Start of organized gravel extraction } \\
\text { Drainage of Agoulinitsa and Mouria lakes } \\
\text { Irrigation works in the Lower Alfeios Basin }\left(160 \mathrm{~km}^{2}\right) \\
\text { Flokas irrigation dam (diversion dam) } \\
\text { Protection works in the middle Alfeios basin (Archaia Olympia area) }\end{array}$ \\
\hline 1971 & Operation of steam electric power plants in Megalopolis area (2 units x $150 \mathrm{MW})$ \\
\hline 1975 & Operation of one unit of $300 \mathrm{MW}$ \\
\hline 1989 & Operation of one unit of $300 \mathrm{MW}$ \\
\hline 1996 & Ban of gravel extraction in the Lower Alfeios Basin \\
\hline \multirow[t]{3}{*}{2000} & $\begin{array}{l}\text { Alfeios declaring bed as an archaeological site and ban of gravel extraction in the } \\
\text { area of Ancient Olympia }\end{array}$ \\
\hline & $\begin{array}{l}\text { Small hydroelectric power plant of Lampia (Divri) with max power capacity of } 1.3 \\
\text { MW }\end{array}$ \\
\hline & Maintenance of the eroded spillway foundation of the Flokas Dam \\
\hline 2002 & Diversion of Alfeios River bed in the area of Megalopolis for lignite extraction \\
\hline 2010 & Start up of Flokas Dam hydroelectric station (6.594 MW) \\
\hline 2011 & $\begin{array}{l}\text { Start up of operation of water treatment plant at Erymanthos River and pipeline } \\
\text { system for drinking water supply of Municipalities of Pyrgos and Archaia Olympia }\end{array}$ \\
\hline 2012 & $\begin{array}{l}\text { Sewage pipeline network and small treatment units for the community of } \\
\text { Koutsochera lleias }\end{array}$ \\
\hline 2013 & Operation of a natural gas electric power plant in Megalopolis (unit V of $811 \mathrm{MW}$ ) \\
\hline
\end{tabular}
Source: Manariotis and Yannopoulos (2004); Bekri and Yannopoulos (2012); PPC (2012)

Along Alfeios River and its tributaries several activities have been developed and adverse effects resulted from residences, tourism, agriculture, industry, instream gravel mining, municipal and industrial wastewater disposal, fly ash and fertilizers. It should be noted that the annual fertilizer use 
in the part of Alfeios basin located in Ileias Prefecture approached $30 \times 10^{6} \mathrm{~kg}$ in 1993 . Water is pumped from the river for drinking water supply, irrigation, or animal consumption, and the basin has long served as the main gravel reservoir for the nearby area; up to the mid-1990s, gravel was primarily extracted from the Lower Alfeios Basin (downstream Flokas Dam). However, the need to protect the archaeological site of Archaia Olympia has enacted the ban of gravel mining downstream Flokas Dam. The main infrastructure works constructed in the Alfeios River basin and the gravel extraction activities are briefly described in Table 1 in chronological order. The construction and operation of infrastructure works in conjunction with the gravel extraction are associated with longterm hydromorphological changes, which have caused adverse impacts on the river ecosystem and secondary impacts on the safety of infrastructure. Furthermore, increased resources have been required for maintenance purposes due to the gravel extraction.

The lignite extraction for operation of steam electric power plants in the Megalopolis terrain have caused geomorphologic alterations. Despite the fact that the lignite constitutes a significant resource for the national economy, the degradation of the ecosystem from lignite extraction and air pollution cannot be ignored.

\section{METHODS}

\subsection{Water quality and discharge}

The Alfeios River water quality was determined at 10 sampling points (Figure 1) during the period 1991-98 in order to assess the changes along the river and to identify the pressures from the different activities. The above time interval included periods before and after the ban of gravel extraction in 1996. The water samples were analyzed according to Standard Methods (APHA et al., 1989). Sulfate ions were measured by a turbidimetric method. Absorbance was measured at $420 \mathrm{~nm}$ with a spectrophotometer (U-1100, Hitachi, Tokyo, Japan). The field measurements of $\mathrm{pH}$, electrical conductivity and turbidity were conducted in water samples, while the dissolved oxygen (DO) and water temperature were carried out directly into the river. The river discharge was calculated from the measurement of the cross-section of the flow and the estimation of the mean velocity using floats. A portable pH-meter (model pH-90, WTW, Germany) was used to measure pH electrometrically; conductivity was measured with a conductivity meter (model LF 91, WTW, Germany); dissolved oxygen and temperature were measured with a portable oxygen meter having a membrane electrode (YSI model 57, YSI, USA).

\subsection{River bed alterations}

Field observations were undertaken in 2002 for 14 cross-sections of the river from Delta to Flokas Dam in order to determine alterations occurred in the bed level and the floodplain level compared to the ground level outside the embankments. The results were first compared with area contour maps taken in 1965 to determine the ground level outside the embankments, and, second, with photo maps taken in 1996 to determine the changes of the width of the river bed. It was assumed that the ground level outside the embankments was maintained at the same levels that it had during the embankments construction in 1965, since after that the soil retreat due to flood events ceased.

Flokas Dam was also constructed during the year 1967 and contributed to upstream sediment trapping and flood interception. Therefore, the aforementioned observations and map data were used to calculate the alterations along the river that occurred during the period 1965-1996. More specifically, the level of the river banks, the area of lateral erosion and the volume eroded between successive river cross-sections, as well as the cumulative volume eroded from the river mouth and up to the Flokas Dam were determined. The river conveyance of sediments has been recently estimated by calculating the volume trapped in the reservoir area upstream the Flokas Dam. Sediment volume calculations were based on contour maps of 1965 and Google photos of July 2004, assuming that sediments had filled the area upstream the Flokas Dam approximately up to the crest of the spillway. An in situ observation in December 2009 corroborated the above assumption. 


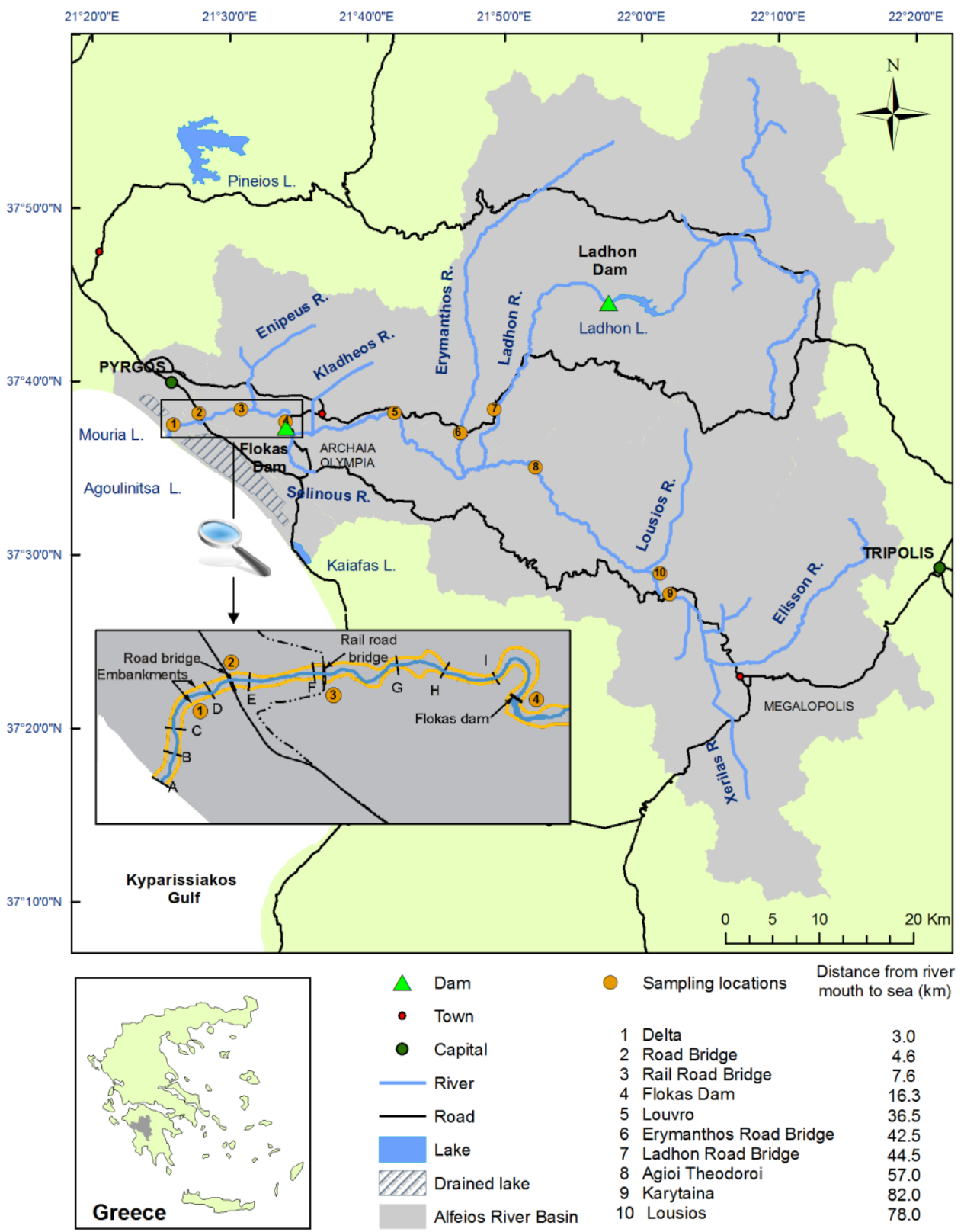

Figure 1. Alfeios River Basin

\section{RESULTS - DISCUSSION}

\subsection{Water quality and discharge}

The variation of discharge, temperature and water quality characteristics measured in ten samplings along the Alfeios River are presented in Figures 2 and 3. Figure 2 includes the water quality parameters that mainly depend on flow, while Figure 3 the parameters due to anthropogenic input. Dissolved oxygen in Alfeios River in upper and medium subbasins was over the saturation level due to higher water velocities, lower flow depth, and higher bed roughness, compared to the lower basin. In any case DO was greater than $7.4 \mathrm{mg} \mathrm{l}^{-1}$ even in the summer period. It is also evident that lower the temperatures, higher the DO concentrations. Turbidity was generally increased with the direction of flow. Based on the samplings of spring, summer and autumn it is observed that turbidity increased downstream the sampling point 4 (Flokas Dam) due to the gravel extraction activities, which had been taking place during this period. The range of $\mathrm{pH}$ values was from 7.5 to 8.4 , showing a slight decrease with the direction of flow. The highest values were observed at sampling point 9 (Karytaina) attributed to the discharge of Megalopolis SEPP wastewater and at sampling point 10 (Lousios River) due to the alkaline composition of soil. Conductivity ranged from 286 to 
$1083 \mu \mathrm{S} \mathrm{cm}^{-1}$. The lower values were observed at sampling points 6 (Erymanthos River) and the highest at sampling point 9 (Karytaina); the increased values at Karytaina were attributed to the wastewater discharged from the Megalopolis Steam Electric Power Plant (SEPP).
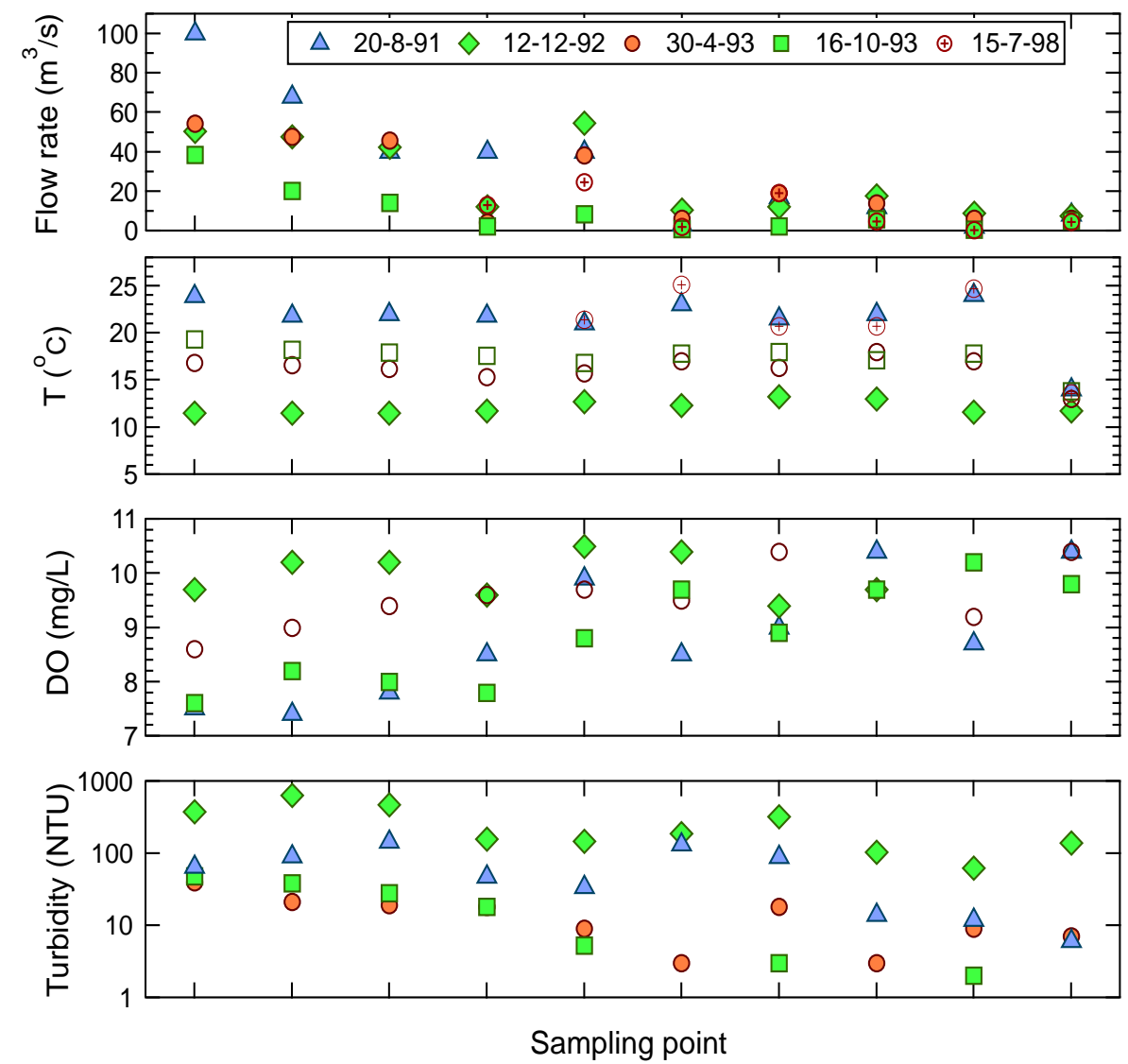

Figure 2. Water quality characteristics in Alfeios River during 1991 and 1998: flow rate, temperature (T), dissolved oxygen (DO) and turbidity

\subsection{Morphological characteristics}

The comparison of data from our field measurement in 2002 in conjunction with data of contour maps taken in 1965 and photo maps in 1996 are shown in Figure 4. The drop of river bank level at different longitudinal sections indicates the impact of gravel extraction combined with the reduced bed load because of the existence of the Flokas Dam. The drop of bank level along the river shows the sand-gravel extraction impact in conjunction with the reduced sedimentation due to Flokas Dam. This drop is maximized downstream the foundations of the bridges and the Flokas Dam and significantly affects their safety.

It should be noted that the beginning of the last decade significant resource were needed for the rehabilitation of infrastructure and mainly their foundations (Ladopoulos, 2000; AMYNTAS, 2004). The maximum drop of the riverbank is estimated to $5.1 \mathrm{~m}$ in a distance of $2.4 \mathrm{~km}$ downstream the dam. In this position a 6.1-m drop of water level was observed from the level outside of the embankments. From field data in the area downstream the Flokas Dam (up to $0.8 \mathrm{~km}$ ), the river bank retreat during the period 1965-97 was $7.0 \mathrm{~m}$ (ETME et al., 1997). This indicates that the riverbank erosion close to the dam was greater than that shown in Figure 4 . The severe river bank retreat combined with the increased water pumping in the summer period causes corresponding drop of groundwater table especially in the areas, outside the embankments. As a result, increased pumping cost and special pumping equipment are required. It should be mentioned that according to long term observations, the water level in wells in the alluvium near the river outside the embankments, during the summer period the last 40 years, was lowered by a maximum of 8 to $10 \mathrm{~m}$. 


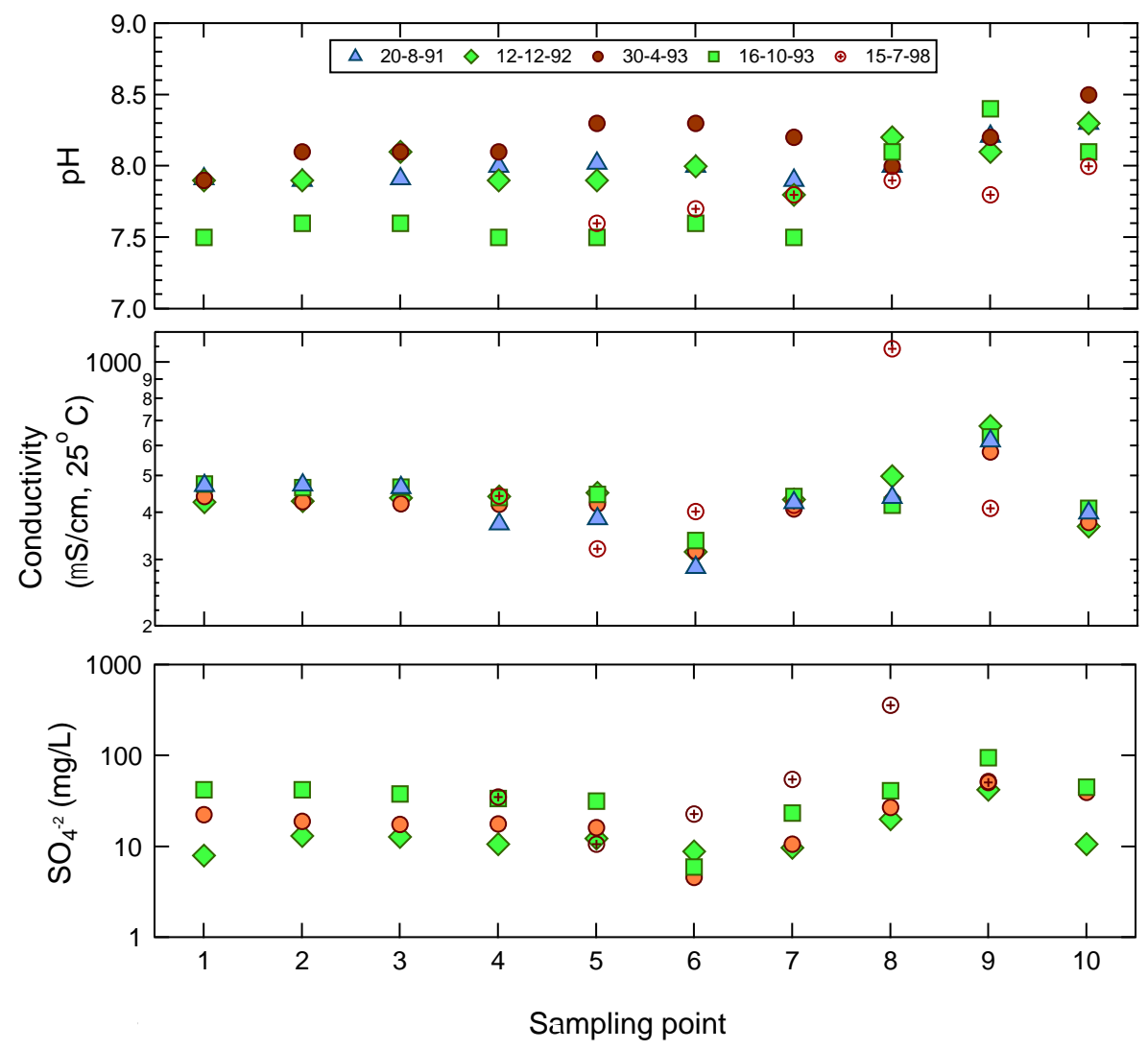

Figure 3. Water quality characteristics in Alfeios River during 1991 and 1998: pH, conductivity and sulfates

The surface and the corresponding volume of erosion calculated between successive sections of the river are illustrated in Figure 4. The erosion level is increased from the delta to the dam. The cumulative erosion volume related to the distance from the Alfeios Delta is also shown in Figure 4. Positive values are observed in a distance up to $1.5 \mathrm{~km}$ from the delta, which are attributed to the accumulation of transported sediments. The greater erosion rate was observed in the downstream area, close to the dam. It should be mentioned that, because of this increased erosion rate, the implementation of large-scale protection works in the order of $3.75 \times 10^{6} €$ was demanded in the period 2000-2004 (Ladopoulos, 2000; AMYNTAS, 2004).

Based on our observations it was estimated that severe erosion had occurred within the embankments area of the Alfeios River reaching the volume of $9.6 \times 10^{6} \mathrm{~m}^{3}$, approximately, during a 32-years period.

Since $17.6 \times 10^{6} \mathrm{~m}^{3}$ (Nicholas et al., 1999) were approximately extracted from 1967 to 1999, i.e. during a 34-years period, the corresponding volume extracted during the period 1965-97, a 32-years period (1965-1997) is $16.6 \times 10^{6} \mathrm{~m}^{3}$; thus, the difference of volume eroded from extracted, which is $7.0 \times 10^{6} \mathrm{~m}^{3}$, should be equal to the volume transported by the river. This volume corresponds to a yearly mean rate of sediment transport of $22 \times 10^{4} \mathrm{~m}^{3}$, which seems to be quite high (Morris and Fan, 1998). Recent data, based on the calculation of volume trapped by the Flokas Dam, indicate a yearly mean rate of sediment transport approximately $3.9 \times 10^{4} \mathrm{~m}^{3}$, a value slightly higher than the values predicted theoretically using sediment transport simulation models (Apion Kleos, 2010). Consequently, the gravel extraction studies from the areas upstream Archaia Olympia should be based on the more reasonable rate of sediment transport $3.9 \times 10^{4} \mathrm{~m}^{3} \mathrm{y}^{-1}$. Gravel extraction from the Lower Alfeios Basin included between the embankments should not be permitted for the present century, because of the need for rehabilitation of the basin.

The river degradation and the bank retreat cause severe impacts to the riverine ecosystem. The drop of groundwater table, in the lower basin of Alfeios River has significantly influenced the flora (Dafis et al., 1996; Yannopoulos and Tsivoglou, 1992; Manariotis and Yannopoulos, 2001), and consequently the fauna. Less severe degradation, due to gravel extraction, was observed in Alfeios River tributaries Erymanthos and Ladhon. 
Table 3. Negative influences on the Alfeios basin due to infrastructure works and their related activities during construction and operation Infrastructure works and related activities Primary impacts Secondary impacts

\begin{tabular}{|c|c|c|}
\hline \multicolumn{3}{|c|}{ Lower Alfeios Basin } \\
\hline $\begin{array}{l}\text { - Embankments, Flokas Dam, Railroad } \\
\text { Bridge, Road Bridge, Irrigation works } \\
\text { - River bank gravel extraction } \\
\text { - Pollutants transport from upstream }\end{array}$ & $\begin{array}{l}\text { Geomorphologic impacts: } \\
\text { - Increased longitudinal erosion rate from the delta toward the Flokas Dam with } 5.1 \mathrm{~m} \\
\text { of maximum bank decline at } 2.4 \mathrm{~km} \text { downstream of the dam } \mathrm{m}^{1,2} \text { and } 7.0 \mathrm{~m} \text { of bank } \\
\text { drop in immediate downstream area up to } 0.8 \mathrm{~km} \text { from } \text { dam }^{3} \text { (maxima observed } \\
\text { immediately downstream of the infrastructure works) } \\
\text { - About } 11.5 \times 10^{6} \mathrm{~m}^{3} \text { of total volume eroded from dam to delta }{ }^{1,2} \\
\text { - About } 9 \mathrm{~m} \text { of cumulative mean channel degradation within the extraction region (8 } \\
\mathrm{km} \times 250 \mathrm{~m})^{4} \\
\text { - Up to } 16 \mathrm{~m} \text { of bank retreat between } 2.5 \text { to } 2.9 \mathrm{~km} \text { downstream of the Flokas Dam } \\
\text { during April } 1994 \text { to April } 1996 \text { period } \\
\text { Water level and quality impacts: } \\
\text { - } 6.1 \mathrm{~m} \text { of maximum surface water level degradation from the level of the outside } \\
\text { embankment fields at } 2.4 \mathrm{~km} \text { downstream the Flokas Dam and } 7.0 \mathrm{~m} \text { up to } 0.8 \mathrm{~km} \\
\text { downstream the dam } \\
\text { - } 8 \text { to } 10 \mathrm{~m} \text { of maximum groundwater table drop in remote locations from the } \\
\text { riverbanks during a } 40 \text {-years period } \\
\text { - Increased turbidity levels } \\
\text { Ecosystem impacts: } \\
\text { - Degradation of the aquatic and riparian ecosystem } \\
\text { - Damage of tufts of riverine forests and other riparian vegetation } \\
\text { - River pathways discontinuity for fish and eel }\left.\right|^{13}\end{array}$ & $\begin{array}{l}\text { - Increased erosion rates due to river straightening } \\
\text { - Elimination of sediment transport downstream of the dam } \\
\text { - Sedimentation processes in the bank area from delta and up to } \\
1.5 \mathrm{~km} \text { upstream }{ }^{1,2} \text {, with low levels at the delta edges } \\
\text { - Considerable erosions of infrastructure works foundations } \\
\text { - Safety risk of infrastructure works } \\
\text { - About } 3.75 \text { million Euros cost of extended foundation } \\
\text { maintenance works for dam protection in } 2001^{1,9,10}\end{array}$ \\
\hline \multicolumn{3}{|c|}{ Middle Alfeios basin } \\
\hline $\begin{array}{l}\text { - Embankments, Ladhon Dam, } \\
\text { Hydroelectric stations, Road Bridges } \\
\text { - Reduced rates of river bank gravel } \\
\text { extraction } \\
\text { - Pollutant transport from upstream }\end{array}$ & $\begin{array}{l}\text { - Channel degradation of less extent in the Alfeios tributaries Erymanthos and Ladhon, } \\
\text { causing less important impacts on water level, water quality and ecosystem } 1,2\end{array}$ & $\begin{array}{l}\text { - Elimination of sediment transport downstream of the dam }{ }^{1,2} \\
\text { - Sedimentation processes in the reservoir dam areas } \\
\text { - Possible effect on archeological site of Olympia } \\
\text { - Ecosystem deterioration }\end{array}$ \\
\hline \multicolumn{3}{|c|}{ Upper Alfeios basin } \\
\hline $\begin{array}{l}\text { - Construction and operation (SEPP, } \\
\text { Road Bridges) } \\
\text { - Lignite mining and usage in the SEPP } \\
\text { - Relocation works of the upper reach ( } 7 \\
\text { km in length) of Alfeios } \\
\text { - SEPP wastewater disposal }\end{array}$ & $\begin{array}{l}\text { - Geomorphologic alterations with ground level degradation } \\
\text { - Groundwater table degradations } \\
\text { - Water quality degradation (coal-black look of the river water, increased turbidity } \\
\text { levels, domestic and industrial wastewater pollution) } \\
\text { - } 1.6 \text { and } 2.0 \text { times higher river water conductivity and sulphate content near the plant } \\
\text { area } \\
\text { - Degradation of the aquatic and riparian ecosystem }{ }^{1,5} \\
\text { - Damage of tufts of riverine forests and other riparian vegetation }{ }^{2}\end{array}$ & $\begin{array}{l}\text { - Air pollution by industrial emissions (fly ash, sulfur dioxide) } \\
\text { - Ecosystem deterioration }{ }^{5,7}\end{array}$ \\
\hline irces & $\begin{array}{l}\text { ariotis and Yannopoulos, } 2004 ;{ }^{3} \text { ETME, } 1997 ;{ }^{4} \text { Nicholas et al., } 1999 ;{ }^{5} \text { Manariotis } \\
;{ }^{9} \text { Ladopoulos } 2000,{ }^{10} \text { AMYNTAS } 2004 .\end{array}$ & 97 \\
\hline
\end{tabular}



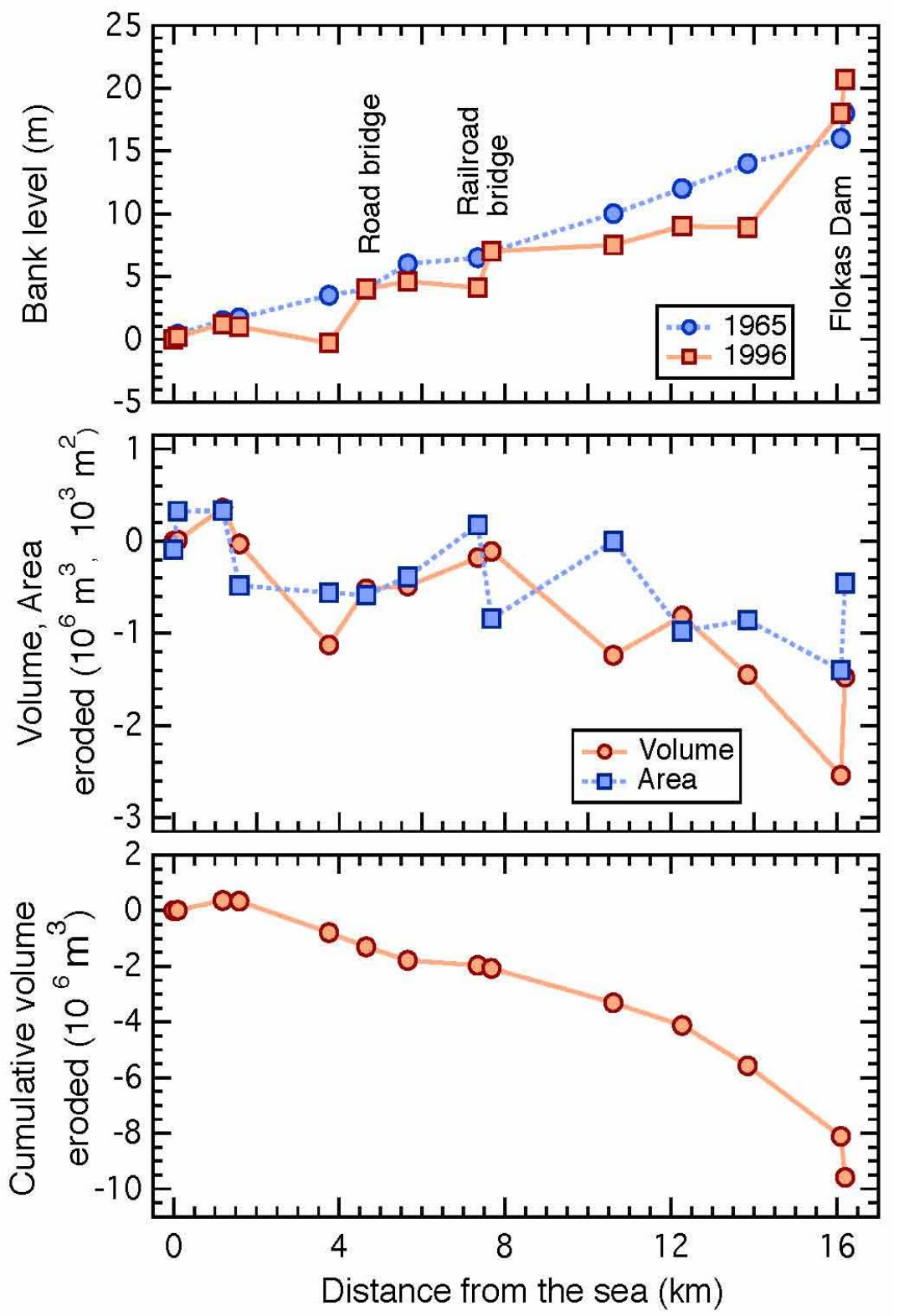

Figure 4. Changes in morphology and erosion along Alfeios River lower basin.

In 2002, the deviation of the Alfeios River channel was implemented at a length of $7 \mathrm{~km}$ in the Megalopolis terrain, in order to exploit the lignite deposits under the natural river bed. Geomorphologic changes from the soil erosion, deterioration of groundwater and surface water quality of Alfeios River, and riverine ecosystem degradation are the main impacts expected to occur in this area. An integrated picture of the primary and secondary impacts caused by infrastructure projects and relevant activities is given in Table 3.

\section{CONCLUSIONS}

Significant impacts on the geomorphological characteristics are observed in the lower basin of Alfeios River. The maximum drop of the river bank is estimated to $5.1 \mathrm{~m}$ from $2.4 \mathrm{~km}$ downstream the Flokas Dam, and in same position the drop of water surface was $6.1 \mathrm{~m}$. The total volume degraded from the Lower Alfeios Basin was estimated to be $9.6 \times 10^{6} \mathrm{~m}^{3}$, occurring during a 32 -years period. It is noticed that the uncontrolled gravel mining caused severe impacts to the foundation of infrastructure works, and demanded costly rehabilitation and protection. The mean rate of the sediment transport was estimated to be $3.9 \times 10^{4} \mathrm{~m}^{3} \mathrm{y}^{-1}$, which implies that ban of gravel mining from the lower river basin should be kept in force during the present century in order to rehabilitate the 
river. Upstream Flokas Dam, gravel mining should be based on studies adopting a rate of sediment transport less than $3.9 \times 10^{4} \mathrm{~m}^{3} \mathrm{y}^{-1}$.

River-bed load is undoubtedly an important resource. For rational decision, a gravel management program, which maximizes the environmental benefits, should be prepared. This program should be included in the integrated management plan for the river basin.

\section{REFERENCES}

Absalon D. and Matysik M. (2007), Changes in water quality runoff in the Upper Oder River Basin, Geomorphology, 92, 106-118.

AMYNTAS A.E. (2004), Protection works of the Flokas Dam of Alfeios R. of lleia Prefecture.

APHA (American Public Health Association); American Water Works Association; Water Environment Federation (1989). Standard Methods for the Examination of Water and Wastewater, 17th ed.; edited by L.S. Clesceri , A.E. Greenberg, and R.R. Trussell. American Public Health Association, Washington, D.C.

Apion Kleos, (2010). Investigation of potential impact especially on sediment transport due to aggregate extraction from rivers Alfeios and Erymanthos, Rep. Department of Civil Engineering, University of Patras, Greece. Apion Kleos C.J.V.

Bekri E.S. and Yannopoulos P.C. (2013), The Interplay between the Alfeios (Greece) River Basin components and the exerted environmental stresses: a critical review, Water Air Soil Pollut, 223, 3783-3806.

Carpenter S.R., Caraco N.F., Correll D.L., Howarth R.W., Sharpley A.N. and Smith V.H. (1998), Nonpoint pollution of surface waters with phosphorus and nitrogen, Ecological Applications, 8(3), 559-568.

Dafis S., Papastergiadou E., Georghiou K, Babalonas D., Georgiadis T., Papageorgiou M., Lazaridou T., Tsiaoussi V. (1996), Directive 92/43/EEC The Greek "Habitat" Project NATURA 2000: An Overview. Life Contract B4-3200/94/756, Commission of the European Communities DG XI, The Goulandris Natural History Museum-Greek Biotope/Wetland Centre.

Dassenakis M., Scoullos M., Foufa E., Krasakopoulou E., Pavlidou A. and Kloukiniotou M. (1998), Effects of multiple source pollution on a small Mediterranean river, Applied Geochemistry, 13, 197-211.

ETME (1997), Protection works for the Flokas Dam of Alfeios River. ETME, Antoniou-Peppas and coworkers, Ministry of Environment, Planning and Public Works, Athens, Greece, pp.1-11 and 13.113.45.

HMA (Hellenic Ministry of Agticulture) (1997), Water quality characteristics of rivers and lakes, section of Wastern Peloponnisos. Water quality chatacteristics of Alfeios River 1983-1997. Ministry of Agriculture.

Kepner W.G., Semmens D.J., Bassett S.D., Mouat D.A. and Goodrich D.G. (2004), Scenario analysis for the San Pedro River, analysing hydrological consequences of a future environment, Environmental Monitoring and Assessment, 94, 115 - 27.

Kondolf G.M. (1994), Geomorphic and environmental effects of instream gravel mining, Landscape and Urban Planning, 28, 225-243.

Ladopoulos G.Th. (2000), Underground foundation works of Flokas Dam of Alfeios R. of lleia Prefecture. G. Th. Ladopoulos ATE, Region of Western Greece, Patras, Greece.

Manariotis I.D.and Yannopoulos P.C. (2001), Environmental impact of riverine activities on Alfios River and measures toward sustainability, In: Proc. Int. Conf. Ecological Protection of the Planet Earth I, Tsihrintzis V.A., Tsalides P. (Eds.), June 5-8, 2001, Xanthi, Greece, Vol. 1, 131-139.

Manariotis I.D. and Yannopoulos P.C. (2004), Adverse effects on Alfeios River Basin and an integrated management framework based on sustainability, Environmental Management, 34(2), 261-269.

Massoud M.A., El-Fadel M., Scrimshaw M.D. and Lester J.N. (2006), Factors influencing development of management strategies for the Abou Ali River in Lebanon I: Spatial variation and land use, Science of the Total Environment, 362, 15-30.

Morris G. L., Fan J. (1998), Reservoir sedimentation Handbook, McGraw-Hill. 
Newson M.D., Newson C.L. (2000), Geomorphology, ecology and river channel habitat: mesoscale approaches to basin-scale challenges, Progress in Physical Geography, 24(2), 195-217.

Nicholas A.P., Woodward J.C., Christopoulos G., Macklin M.G. (1999), Modelling and monitoring river response to environmental change: The impact of dam construction and alluvial gravel extraction on bank erosion rates in the lower Alfios basin, Greece. In: Fluid Processes and Environmental Change, Brown, A.G., Quine, T.A. (Eds.), John Wiley \& Sons Ltd., NY, pp. 117-137.

Peters N. and Meybeck M. (2000), Water quality degradation effects on freshwater availability: impacts of human activities, Water International, 25(2), 185-193.

PPC S.A. (2012). Annual Report 2011, Part B' Executive summary of the Board of Directors (p. 30), Public Power Corporation, Athens.

Rinaldi M., Wyzga B. and Surian N. (2005), Sediment mining in alluvial channels: physical effects and management perspectives, River Research and Applications, 21, 805-828.

Simeonov V., Stratis J.A., Samara C., Zachariadis G., Voutsa D, Anthemidis A., Sofoniou M. and Kouimtzis Th. (2003), Assessment of the surface water quality in Northern Greece, Water Research, 37, 4119-24.

Wishart D., Warburton J. and Bracken L. (2008), Gravel extraction and planform change in a wandering gravel-bed river: The River Wear, Northern England, Geomorphology, 94, 131-152.

Yannopoulos P.C. and Tsivoglou I. (1992), Impact of riverine activities on Alfeios River water quality. In Proc.1st National Congress of the Greek Committee for the Water Resources Management, Kaimaki S. (Eds.), November 18-20 1992, Athens, 197-204 (in Greek). 